\title{
Value of joint scintigraphy in the prediction of erosiveness in early rheumatoid arthritis
}

\author{
T T MÖTTÖNEN, ${ }^{1}$ P HANNONEN, ${ }^{1}$ J TOIVANEN, ${ }^{2}$ A REKONEN, ${ }^{2}$ AND \\ $\mathrm{MOKA}{ }^{1}$
}

From the ${ }^{1}$ Department of Medicine and the ${ }^{2}$ Isotope Laboratory, Central Hospital SF-40620 Jyväskylä, Finland

SUMmARY The value of scintigraphy in predicting development of new erosions in small peripheral joints was studied by visual evaluation of scintigrams and by three computerised methods. In 13 patients with newly diagnosed rheumatoid arthritis a total of 387 joints were examined clinically, scintigraphically, and radiographically. The follow up period was 24 months. Four eroded joints in three patients were found at the onset. Of the joints which were to become eroded, $46 / 47$ were scintigraphically active at all the check ups. Erosions were detected earlier in foot joints than in finger joints. New erosions were especially prone to appear in joints with persisting and high scintigraphic activity. On the contrary, inactive joints by repeated scanning never eroded. Scintigraphic and clinical activity and radiographic erosiveness correlated significantly with each other. The sensitivity and specificity of visual scintigraphic assessment and the relative pixel activity method proved to be superior to the region of interest methods and clinical evaluation for prediction of erosiveness.

Key words: ${ }^{99 m} \mathrm{Tc}$ methylene diphosphonate, peripheral joints.

Rheumatoid arthritis (RA) is a systemic inflammatory disease characterised by polyarthritis. Joint inflammation typically affects small peripheral joints, where bone erosions are also first seen. ${ }^{1}$ Erosiveness is the most important criterion of progressive arthritis and an indication for prompt institution of second line antirheumatic drug treatment. ${ }^{2}$ Because clinical judgment is often inaccurate, objective methods are urgently needed to predict erosiveness of RA.

Joint scintigraphy is an objective method of demonstrating and assessing joint inflammation. ${ }^{3-5}$ Accumulation of bone seeking radioisotopes reflects metabolic activity of bone and blood pooling in the joint. Skeletal scintigraphy is a more selective method for the detection of joint inflammation than radiography and more sensitive than clinical evaluation. ${ }^{6}$ In erosive osteoarthritis the scan abnormality appears to precede the development of radiographic progression. ${ }^{7}$ The results for scintigraphy in RA are controversial. Although

Accepted for publication 15 August 1987.

Correspondence to Dr T T Möttönen, Department of Medicine, Central Hospital, SF-40620, Jyväskylä, Finland.
Desaulniers and coworkers reported that an abnormal scintigram may antedate clinically or radiographically detectable involvements in $\mathrm{RA}^{6}{ }^{6}$ Pitt and others found no apparent association between isotope uptake and development of erosions. ${ }^{8}$ The aim of the present study was to find out whether serial joint scintigraphies assessed both visually and by computerised methods offer any advantage over clinical judgment in the prediction of new erosions in peripheral small joints of patients with recent onset RA.

\section{Patients and methods}

Thirteen consecutive patients (six female, seven male) with definite RA, ${ }^{9}$ aged $21-62$ years (mean 48), were followed up for 24 months. The duration of the disease ranged from 2 to 24 months (mean 9). Seven patients had rheumatoid factor titres of $1 / 64$ or more as measured by the Waaler-Rose test. Second line antirheumatic drug treatment was started for all the patients. Clinical assessment and joint scintigraphy were carried out on the same day, before treatment was started and six and 12 months later. $x$ Rays of the hands and feet were taken at 0 , 
$6,12,18$, and 24 months. Joint tenderness (0-3 points) was recorded as described by Ritchie and coworkers $^{10}$ and scored separately for each metacarpophalangeal (MCP) joint, proximal interphalangeal (PIP) joint of the fingers, interphalangeal (IP) joint of the first toe, and II-V metatarsophalangeal (MTP) joints. Joint swelling and palpable effusion were given scores from 0 to 2 . The clinical activity of each joint during the period of observation was determined by adding together the scores of assessments at 0,6 , and 12 months (score range 0-15).

Radiological erosiveness of the joints was estimated by the method of Larsen, Dale, and Eek. ${ }^{11}$ The bone seeking radionuclide ${ }^{99 \mathrm{~m}} \mathrm{Tc}$ methylenediphosphonate ( $\left.{ }^{99 \mathrm{~m}} \mathrm{Tc} \mathrm{MDP}\right)\left(370 \mathrm{MBq} / \mathrm{m}^{2}\right)$ was administered intravenously, and pictures were taken after three hours. Hands were imaged using palmar projection, and feet using plantar projection, with an imaging time of $500 \mathrm{~s}$. The gamma pictures were evaluated by the following methods: (a) Visual activity was assessed by comparing the gray scale scintigrams with the pictures of non-inflamed control joints (inactive, active, highly active). (b) The computerised region of interest method (ROI) was applied without an internal standard or $(c)$ using an internal standard in the analysis. Reference values were obtained by the scintigraphic analysis of six healthy controls. The methods and their reference values have been described earlier in detail. ${ }^{12}(d) \mathrm{A}$ new method, relative pixel activity, for measurement of the radionuclide uptake in the examined joint was developed for this study. It is based on the determination of maximal activity in one pixel, thus eliminating the laborious manual tracing of joint limits necessary in the ROI methods. (A pixel is a single picture element in an image derived from recording radiation emanating from an administered radioactive material.) Each picture was normalised to maximum as $100 \%$. The upper threshold was thereafter lowered by computer in 5\% steps and a series of gamma pictures obtained (Fig. 1). The areas exceeding the threshold were displayed as empty pixels. Step by step an empty pixel was found in every joint at a certain percentage level. The percentage level at which an empty pixel appeared in the joint was the value of maximal pixel activity of the joint concerned. Relative pixel activity was determined by calculating the difference between the maximal activities of the inflamed joint and the inactive joint showing the lowest maximal activity. The MCP joints were compared with each other and the PIP joints with each other. The IP joint of the thumb was compared with the MCP joints and the IP joint of the first toe with the MTP joints. The joint was considered inactive when a visual compari- son with the control joints showed no difference between them.

The mean reference values of the MCP and PIP joints by the relative pixel activity method were 9.4(7.5) (mean(SD), range 0-25). The corresponding figures in the II-V MTP joints and the IP joint of the first toe were 5.3(4.8) (range $0-15$ ).

Clinical evaluation and scoring of $x$ rays and scintigrams were always performed by the same person (TTM).

The mean scintigraphic activity of each joint was the mean of the values obtained at 0,6 , and 12 months. The isotope uptake in the joint was considered to be increased when the figures exceeded the reference values by $2 \mathrm{SD}$.

Decision matrices ${ }^{13}$ were constructed to relate clinical and isotope activities to the development of new erosions during the follow up. The significance of differences between the means of the groups was determined by two tailed Student's $t$ test, and correlations were obtained by Spearman's rank correlation.

The radiation dose of three ${ }^{99 \mathrm{~m}} \mathrm{Tc}$ MDP isotope studies did not exceed the dose of one lumbosacral radiography.

Consent for our study was granted by the ethics committee of the Central Hospital of Jyväskylä.

\section{Results}

Two hundred and fifty seven finger joints and 130 foot joints of 13 patients with RA were evaluated. Four eroded joints in three patients were found at the start of the study, two in MCP joints and two in foot joints (Table 1). The eroded MCP joints were active both clinically and scintigraphically, whereas the eroded foot joints were inactive in the scintigrams despite slight clinical activity in the other joint. Twenty eight new eroded joints were found in nine patients at the 12 months' assessment, 22 in the feet and six in the fingers (Table 1). A further 19 joints (10 in feet, nine in fingers) which became eroded in eight patients during the subsequent 12 month period were detected at 24 months (Table 1). Only one patient remained non-erosive during the whole follow up period.

\section{FINGER JOINTS}

All the six eroded finger joints at 12 months (Table 1) were active both clinically and scintigraphically at the 0,6 , and 12 months' assessments apart from one joint in which scintigraphic activity preceded clinical activity. Furthermore, six of the nine eroded joints at 24 months were scintigraphically inactive at the onset of the follow up, but active at the 6 and 12 month evaluations. 


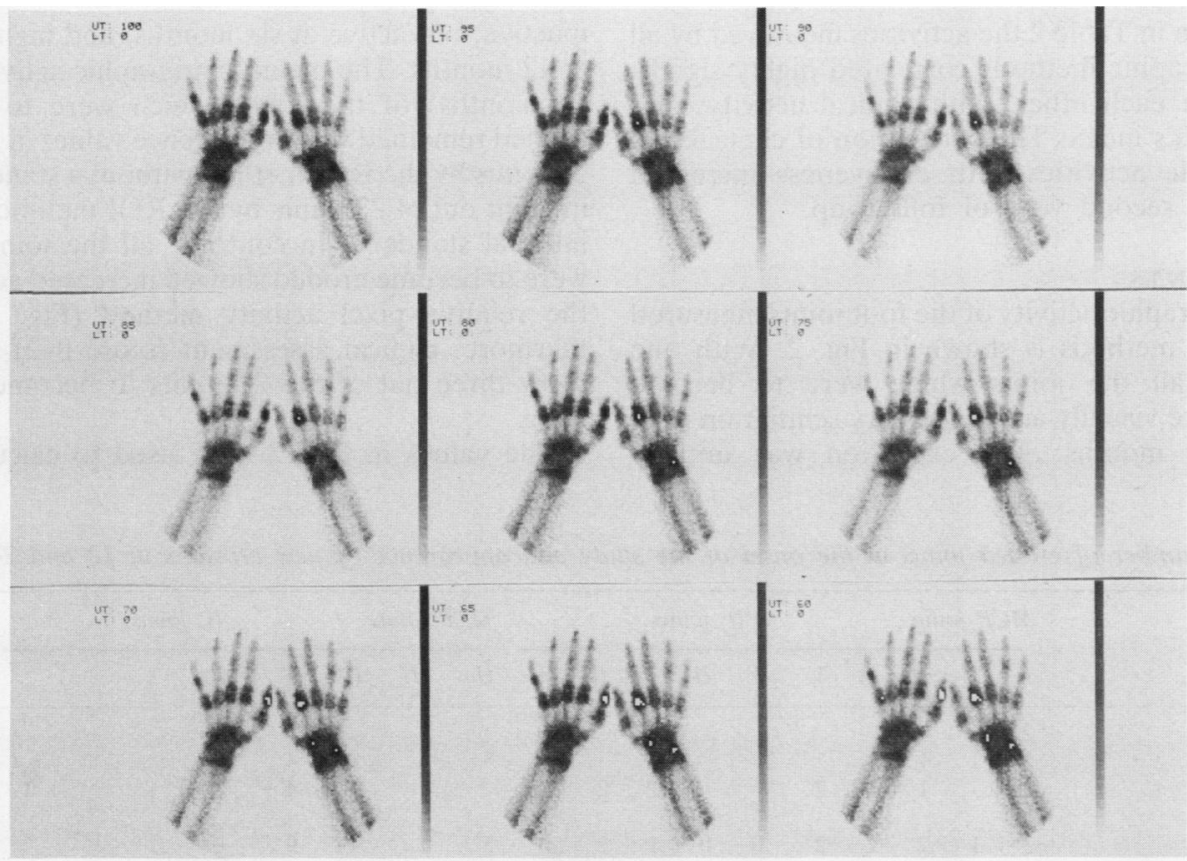

Fig. 1a

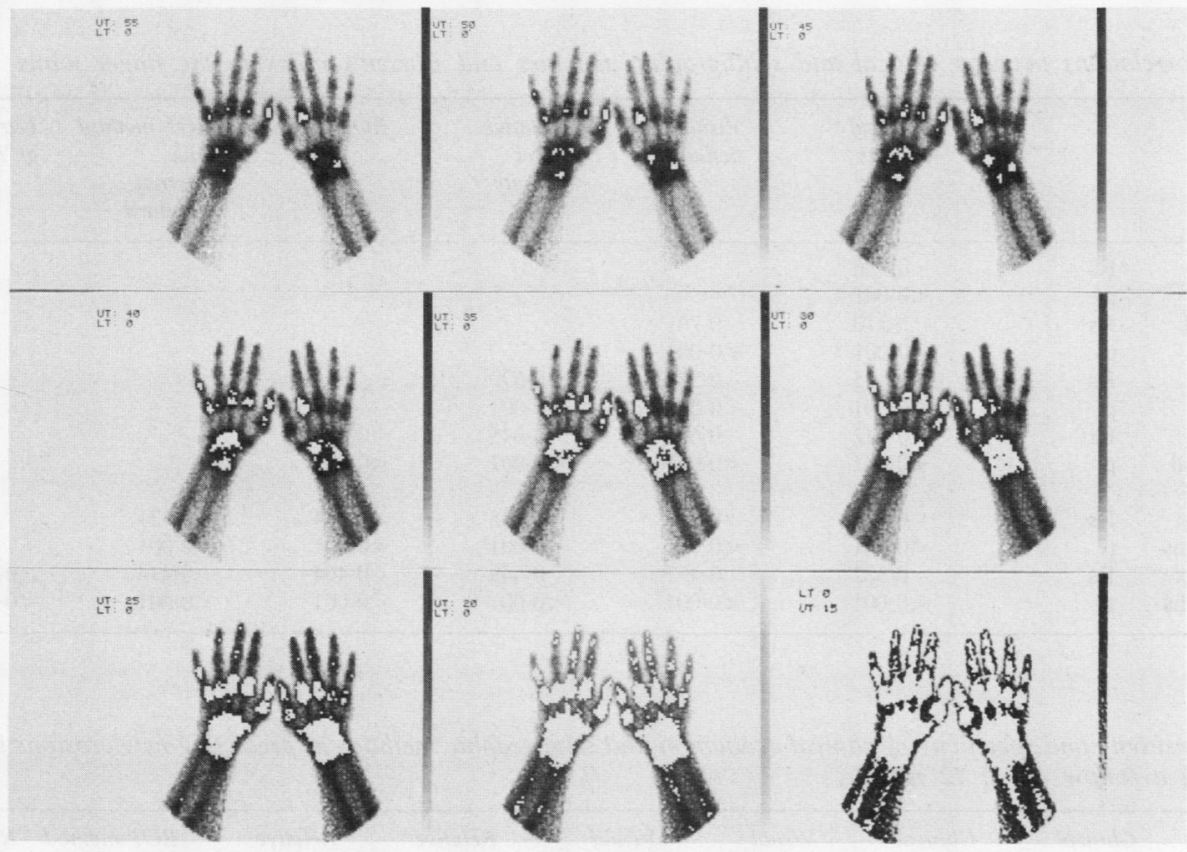

Fig. 1b

Fig. 1 Scintigram of the hands evaluated by the relative pixel activity method. The most active joint, in which an empty pixel first appears at the $95 \%$ level, is the MCP II joint of the left hand. The pixel activity in the scintigraphically inactive $M C P V$ joint of the left hand is $25 \%$. The difference between these values (95-25) is the relative pixel activity of the left $M C P$ II joint. The relative pixel activity of the right IP I joint is $45 \%(70-25)$. (UT=upper threshold; $L T=$ lower threshold.) 
As shown in Table 2 the activities measured by all the scintigraphic methods correlated highty significantly with each other, with clinical activity, and with Larsen's index. The correlation of clinical and scintigraphic activities with erosiveness increased during the second year of follow up.

\section{FOOT JOINTS}

The scintigraphic activity of the foot joints measured by various methods is shown in Fig. 2 . With one exception all the joints which were to become eroded were visually active in every scintigram at 0 , 6 , and 12 months. The exception was initially inactive, but active at six months, and highly active at 12 months. The mean scintigraphic activity $(0,6 \underset{\mathrm{F}}{\overrightarrow{7}}$ 12 months) of the joints which were to become eroded remained within reference values in 13 out of 22 joints by the ROI method without a standard and in eight out of 22 joints by the ROI method with aro internal standard. In contrast, all the joints which were to become eroded showed increased activity by the relative pixel activity method (Fig. 2). Fur? thermore, clinical assessment (score 0-2) failed to show three out of the 22 joints to become erodew later.

The values in Fig. 2 were used to calculate the

Table 1 Number of eroded joints at the onset of the study and appearance of new erosions at 12 and 24 monthso⿰

\begin{tabular}{|c|c|c|c|c|c|c|c|c|c|c|c|c|c|c|c|c|}
\hline \multirow{2}{*}{$\begin{array}{l}\text { Period of } \\
\text { follow up } \\
\text { (months) }\end{array}$} & \multicolumn{5}{|c|}{$M C P$ joints } & \multicolumn{5}{|c|}{ PIP joints } & \multicolumn{4}{|c|}{$M T P$ joints } & \multirow{2}{*}{$I_{I}^{I P \text { joints }}$} & \multirow{2}{*}{$\begin{array}{l}\text { No of } \\
\text { eroded } \\
\text { joints }\end{array}$} \\
\hline & $I$ & II & III & IV & $V$ & $I$ & II & III & IV & $V$ & II & III & IV & $V$ & & \\
\hline 0 & 2 & & & & & & & & & & & & & 1 & 1 & 4 \\
\hline 12 & 1 & 1 & 1 & 1 & & & & & & 2 & 5 & 4 & 5 & 4 & 4 & 28 \\
\hline 24 & & & 1 & 1 & 2 & & & 1 & 2 & 2 & & 1 & 4 & 4 & 1 & 19 \\
\hline Total & 3 & 1 & 2 & 2 & 2 & 0 & 0 & 1 & 2 & 4 & 5 & 5 & 9 & 9 & 6 & 51 \\
\hline
\end{tabular}

Table 2 Correlations between clinical and scintigraphic activities and Larsen's index in the finger joints

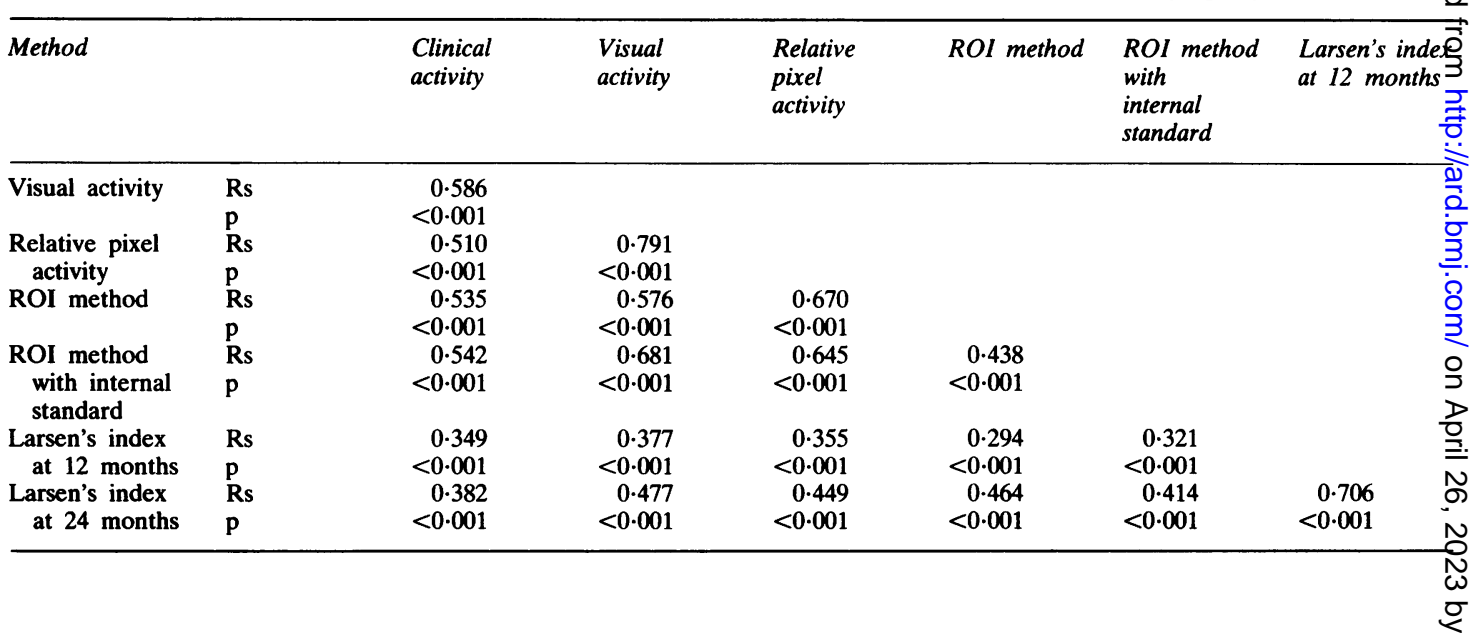

Table 3 Sensitivity and specificity of clinical evaluation and scintigraphic methods in predicting new erosions in the foof joints during a follow up of 12 months

\begin{tabular}{|c|c|c|c|c|c|c|c|c|}
\hline & $\begin{array}{l}\text { Clinical } \\
\text { activity } \\
\text { (score } \geqslant 3)\end{array}$ & $\begin{array}{l}\text { Clinical } \\
\text { activity } \\
(\text { score } \geqslant 6)\end{array}$ & $\begin{array}{l}\text { Visual } \\
\text { activity } \\
\text { (score }>2)\end{array}$ & $\begin{array}{l}\text { Visual } \\
\text { activity } \\
\text { (score 5-6) }\end{array}$ & $\begin{array}{l}\text { Relative } \\
\text { pixel } \\
\text { activity } \\
(>2 S D)\end{array}$ & $\begin{array}{l}\text { Relative } \\
\text { pixel } \\
\text { activity } \\
(>20 \%)\end{array}$ & $\begin{array}{l}\text { ROI method } \\
(>2 S D)\end{array}$ & $\begin{array}{l}\text { ROI method } \\
\text { with interna } \\
\text { standard } \\
(>2 S D)\end{array}$ \\
\hline Sensitivity (\%) & 86 & 64 & 100 & 86 & 100 & 100 & 41 & 64 \\
\hline Specificity (\%) & 46 & 76 & 75 & 95 & 80 & 90 & 81 & 85 \\
\hline
\end{tabular}


sensitivity and specificity of clinical evaluation and scintigraphic methods in predicting new erosions in the foot joints (Table 3 ). Visual activity and relative pixel activity were better than the other methods in disclosing the eroded joints. These methods also succeeded best in predicting erosiveness. Higher scores of visual and clinical activities and values higher than two standard deviations in relative pixel activity increased the specificity. This resulted in a simultaneous lowering of sensitivity except in the relative pixel activity, which remained as $100 \%$. The ROI methods appeared to be highly specific, but

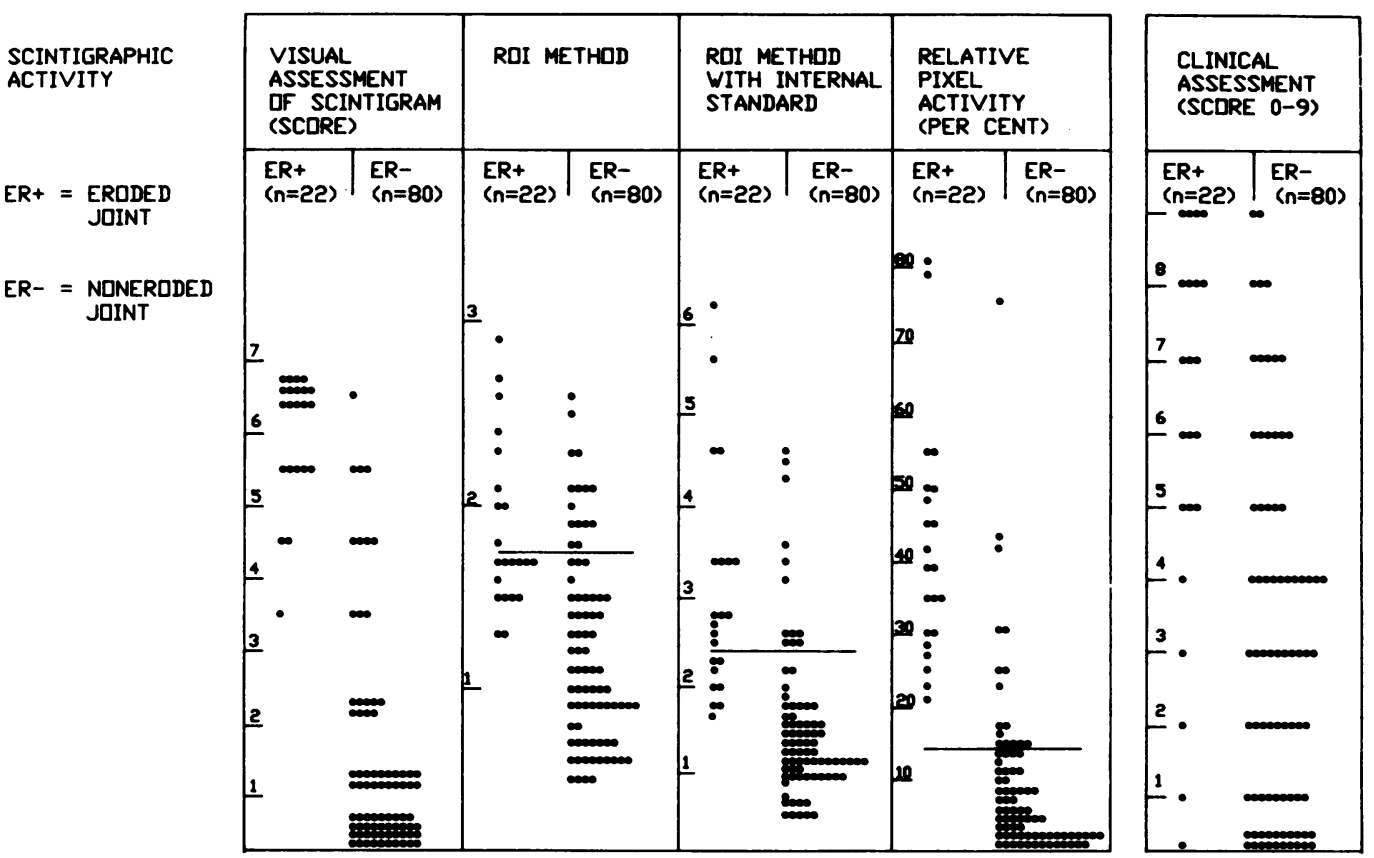

Fig. 2 Scintigraphic and clinical activities in eroded and non-eroded feet joints. The initially eroded joints, the joints with suspected erosions at 18 months (Larsen's score 1), and joints with new erosions at 24 months were excluded from the analysis (28 joints). Horizontal lines represent the mean (2SD) of the reference values.

Table 4 Correlations between clinical and scintigraphic activities and Larsen's index in the foot joints

\begin{tabular}{|c|c|c|c|c|c|c|c|}
\hline Method & & $\begin{array}{l}\text { Clinical } \\
\text { activity }\end{array}$ & $\begin{array}{l}\text { Visual } \\
\text { activity }\end{array}$ & $\begin{array}{l}\text { Relative } \\
\text { pixel } \\
\text { activity }\end{array}$ & ROI method & $\begin{array}{l}\text { ROI method } \\
\text { with } \\
\text { internal } \\
\text { standard }\end{array}$ & $\begin{array}{l}\text { Larsen's index } \\
\text { at } 12 \text { months }\end{array}$ \\
\hline Visual activity & $\begin{array}{l}\text { Rs } \\
\text { p }\end{array}$ & $\begin{array}{r}0.243 \\
=0.006\end{array}$ & & & & & \\
\hline $\begin{array}{l}\text { Relative pixel } \\
\text { activity }\end{array}$ & $\begin{array}{l}\text { Rs } \\
\text { p }\end{array}$ & $\begin{aligned} & 0.278 \\
= & 0.002\end{aligned}$ & $\begin{array}{r}0.910 \\
<0.001\end{array}$ & & & & \\
\hline ROI method & $\begin{array}{l}\text { Rs } \\
\text { p }\end{array}$ & $\begin{array}{l}0 \cdot 123 \\
\text { NS }\end{array}$ & $\begin{array}{r}0.649 \\
<0.001\end{array}$ & $\begin{array}{r}0.703 \\
<0.001\end{array}$ & & & \\
\hline $\begin{array}{l}\text { ROI method } \\
\text { with internal } \\
\text { standard }\end{array}$ & $\begin{array}{l}\text { Rs } \\
\text { p }\end{array}$ & $\begin{array}{r}0.287 \\
=0.001\end{array}$ & $\begin{array}{r}0.784 \\
<0.001\end{array}$ & $\begin{array}{r}0.830 \\
<0.001\end{array}$ & $\begin{array}{r}0.743 \\
<0.001\end{array}$ & & \\
\hline $\begin{array}{l}\text { Larsen's index } \\
\text { at } 12 \text { months } \\
\text { Larsen's index } \\
\text { at } 24 \text { months }\end{array}$ & $\begin{array}{l}\text { Rs } \\
\text { p } \\
\text { Rs } \\
\text { p }\end{array}$ & $\begin{array}{r}0.224 \\
=0.011 \\
0.328 \\
<0.001\end{array}$ & $\begin{array}{r}0.590 \\
<0.001 \\
0.682 \\
<0.001\end{array}$ & $\begin{array}{r}0.528 \\
<0.001 \\
0.631 \\
<0.001\end{array}$ & $\begin{array}{r}0.438 \\
<0.001 \\
0.450 \\
<0.001\end{array}$ & $\begin{array}{r}0.448 \\
<0.001 \\
0.492 \\
<0.001\end{array}$ & $\begin{array}{r}0.735 \\
<0.001\end{array}$ \\
\hline
\end{tabular}


their sensitivity was poor (Table 3 ). Clinical assessment was inferior to all the scintigraphic methods for prediction of erosions in the foot joints.

The correlations of the mean activities measured by clinical and scintigraphic methods with the development of radiographic destruction are shown in Table 4. Scintigraphic methods correlated statistically significantly with each other and with the development of new erosions. In addition, clinical assessment correlated statistically significantly with the development of erosions, but the correlation coefficients were smaller than those obtained by scintigraphic methods (Table 4).

\section{Discussion}

Several chemical and immunological markers have been claimed to predict disease progression or development of erosions in RA. These include rheumatoid factor, ${ }^{14} 15$ erythrocyte sedimentation rate,${ }^{16}$ anaemia ${ }^{17}$ serum $C$ reactive protein,${ }^{18}$ serum C1q level, ${ }^{19}$ and circulating immune complexes. ${ }^{20}$

In the present prospective study four scintigraphic methods were tested for their ability to predict erosiveness of peripheral small joints in patients with recent onset RA. During a follow up period of 24 months the number of erosions in the radiograms increased from four to 51. Evaluation of visual activity and relative pixel activity proved to be superior to both the ROI methods and clinical evaluation in sensitivity and specificity. It was remarkable that all the joints which were to become eroded during the first 12 months were scintigraphically active in all the examinations at 0,6 , and 12 months, with the exception of one joint. All the scintigraphic results correlated with each other and with clinical activity and Larsen's index. Correlation between scintigraphic and clinical activities was clearly better in finger joints than in foot joints. This increased the usefulness of scintigraphy in the detection of early involvement of peripheral foot joints. Clinical assessment, too, correlated significantly with the development of new erosions but to a lower degree than scintigraphy.

The study showed that the process of bone destruction is faster in feet than in fingers. More than two thirds of the erosions found in the feet at 24 months were already noticeable at 12 months, whereas in the fingers most new erosions $(60 \%)$ developed during the second year of the follow up. Correlations between scintigraphic activities and Larsen's index were correspondingly improved during this period.

Our study showed that laborious computerised methods do not offer any special advantage over the visual evaluation of scintigrams, which appeared to be the method of choice. Previous suggestions that scintigraphic activity may antedate the developmen of erosions ${ }^{621-23}$ were confirmed. On the othe hand, our results were in contrast with those obtained by Pitt and her coworkers, ${ }^{8}$ who found n⿳亠口冋. association between scintigraphy and erosions. I8 their study patients with early RA were not include and the scanning was performed just once. In ouf study the patients suffered from active RA of shoळ duration (range 2-24 months, mean 9) and seriat scannings were performed. This probably accounf for the difference between the two sets of results

We conclude that joint scanning with ${ }^{99 \mathrm{~m}} \mathrm{Tc}$ MD is a valuable tool in the prediction of rheumatoid erosions. Scintigraphic activity correlates with clinie cal activity but is more sensitive than clinic assessment. Erosions are most likely to develop it joints showing high radionuclide uptake, particu larly when high activity persists. In a few case erosions may develop in joints which are initiale inactive but later become scintigraphically active Joints inactive by repeated scanning never erodछ

\section{References}

1 Brook A, Corbett M. Radiographic changes in early rheum toid disease. Ann Rheum Dis 1977; 36: 71-3.

2 Luukkainen R. Chrysotherapy in rheumatoid arthritis with particular emphasis on the effect of chrysotherapy on radif graphical changes and on the optimal time of initiation $\mathbb{A}$ therapy. Scand J Rheumatol [Suppl] 1980; 34: 26-8.

3 Dick W C, Deodhar S D, Provan C J, Nuki G, Buchanan W w Isotope studies in normal and diseased joints: $99 \mathrm{~m}-\mathrm{Tc}$ uptaks related to clinical assessment and synovial perfusion method the 133-Xenon clearance technique. Clin Sci 1971; 40: 327-3R.

4 Wallace D J. Brachman M, Klinenberg J R. Joint scanning rheumatoid arthritis-a literature review. Semin Arthrit Rheum 1981; 11: 172-6.

5 Oka M, Möttönen T, Rekonen A. Clinical results in th evaluation of peripheral joints by radionuclide methods. In Kolarz G, Thumb N, eds. Methods of nuclear medicine $\$$ rheumatology. Stuttgart: Schattauer, 1982: 67-88.

6 Desaulniers M, Fuks A, Hawkins D, Lacourciere Y, Rosenthat L. Radiotechnetium polyphosphate joint imaging. $J$ Nucl Med 1974; 15: 417-23.

7 Hutton C W, Higgs E R, Jackson P C, Watt I, Dieppe P ${ }^{99 m} \mathrm{Tc}$ HMDP bone scanning in generalised nodal osteoarthritisu II. The four hour bone scan image predicts radiographis change. Ann Rheum Dis 1986; 45: 622-6.

8 Pitt P, Berry H, Clarke M, Foley H, Barratt J, Parsons Metabolic activity of erosions in rheumatoid arthritis. A $A$ ( Rheum Dis 1986; 45: 235-8.

9 Ropes M W, Bennett G A, Cobb S, et al. Diagnostic criteria fog rheumatoid arthritis. Ann Rheum Dis 1959; 18: 49-53.

10 Ritchie D M, Boyle J A, McInnes J M, et al. Clinical studis with an articular index for the assessment of joint tenderness in patients with rheumatoid arthritis. $Q J$ Med 1968; 27: 393-80

11 Larsen A, Dale K, Eek M. Radiographic evaluation of rheumatoid arthritis and related conditions by standard refê⿱ ence films. Acta Radiol [Diagn] (Stockh) 1977; 18: 481-9

12 Möttönen T T, Hannonen P, Toivanen J, Rekonen A, Oka 1. Scintigraphy of rheumatoid peripheral joints. Reliability of visual assessment $v$ computerized methods. Scand J Rheumatol (in press). 
13 Griner P F, Mayewski R J, Mushlin A I, Greenland P. Selection and interpretation of diagnostic tests and procedures: Principles and applications. Ann Intern Med 1981; 94: 553-600.

14 Bywaters E G L. Curven M, Dresner E, Dixon A. Ten-year follow-up of rheumatoid arthritis. Lancet 1960; ii: 1381 .

15 Teitsson I, Withrington $R$, Seifert $M$, Valdimarsson $H$. Prospective study of early rheumatoid arthritis. I. Prognostic value of IgA rheumatoid factor. Ann Rheum Dis 1984; 43: 673-8.

16 Duthie J J R, Brown P E, Knox J D E, Thompson M. Course and prognosis in rheumatoid arthritis. Ann Rheum Dis 1957; 16: 411-23.

17 Fleming A, Crown J M, Corbett M. Prognostic value of early features in rheumatoid disease. Br Med J 1976; i: 1243-5.

18 Amos R S, Constable T J, Crockson R A, Crockson A P, McConkey B. Rheumatoid arthritis: relation of serum Creactive protein and erythrocyte sedimentation rates to radiographic changes. $\mathrm{Br}$ Med $\mathrm{J}$ 1977; i: 195-7.
19 Ochi T, Yonemasu K, Iwase R, Sasaki T, Tsuyama K, Ono K. Serum C1q levels as a prognostic guide to articular erosions in patients with rheumatoid arthritis. Arthritis Rheum 1984; 27: 883-7.

20 Westedt M-L, Daha M R, Baldwin W M, Stijnen T, Cats A. Serum immune complexes containing IgA appear to predict erosive arthritis in a longitudinal study in rheumatoid arthritis. Ann Rheum Dis 1986; 45: 809-15.

21 Oka M, Möttönen T T, Rekonen A. A comparison of $99 \mathrm{~m}-\mathrm{Tc}$ MDP and $99 \mathrm{~m}-\mathrm{Tc}$ pertechnetate by computerized quantitative joint scintigraphy. Scand J Rheumatol 1983; 12: 46-8.

22 Möttönen T, Hannonen P, Rekonen A, Oka M. Joint scintigraphy and erosions. Ann Rheum Dis 1986; 45: 966-7.

23 Oh B K, Macfarlane J D, Goei H S, Pauwels E K. Sequential joint scintigraphy in rheumatoid arthritis. Clin Rheumatol 1983; 2: $45-51$. 